ホロホロチョウとニワトリの成長初期における卵管の発育, 血漿エストラジオール $-17 \beta$ 濃度の変化及びェストロ
ジェン投与による卵管重量の増加について

\author{
小川 博・桑山岳人**田中克英* \\ 東京農業大学富士畜産農場 富士宮市 418-0109 \\ 東京農業大学農学部畜産学科 世田谷区 156-0054
}

\begin{abstract}
真珠斑のホロホロチョウ（GF）と白色レグホーン種のニワトリ（WL）とについて, 初生時から 10 週 齡までの期間における体重, 卵管重量, 血漿エストラジオール-17 $\beta\left(\mathrm{E}_{2}\right)$ 濃度を 1 週間ごとに測定した。 体重は 3 週齢以降，卵管重量は 4 週龄以降において GF の方が WL よりあ大であった。体重 $100 \mathrm{~g}$ 当た りの卵管重量は GF あWL あともに 2 週齡以降ほとんど変化せず, 両者間の差違も認められなかった。 血漿 $\mathrm{E}_{2}$ 濃度は GF では 8 週齢まで顕著な増加を示さなかったが, WL では 4 週齢以降増加した。 5 週齢 の GF 及びWLにジェチルスチルベストロール $(62.5 \sim 1,000 \mu \mathrm{g} /$ 羽/日）を連続 5 日間筋肉内注射し, 最終注射の 24 時間後における卵管重量の増加率を比較したところ，GF はWLよりも小さかった。ま た, 4 週齢の GF に同様な注射を行った場合の增加率も 5 週齢の WL よりあ小さかった。従って, 10 週 齢までの期間における卵管重量が GF の方が WL よりあ大であることは体重が GF の方が大きいこと に関連することであって，血漿 $E_{2}$ 濃度や卵管のエストロジェンに対する反応性に起因するすのではな いあのと考えられた。
\end{abstract}

（家禽会誌，35：125-131, 1998）

キーワード：卵管成長，ホロホロチョウ，血漿エストラジオール，ジェチルスチルベストロール

\section{緒言}

ホロホロチョウ（GF；Numida meleagris）の生体重 （約 $2.7 \mathrm{~kg}$ ）は卵用種のニワトリ（白色レグホーン種 : WL）のそれ（約 $1.8 \mathrm{~kg}$ ）よりも大きいが, 産卵期におけ る卵管重量（約 $50 \mathrm{~g}$ ）はニワトリ（約 $65 \mathrm{~g}$ ）よりあ小さ い(OGAw A et al., 1996)。このような卵管重量の相違が 成長の初期から生じているのかどうか明らかでない。卵 管の発育は, ニワトリでは卵巣ホルモンの 1 つであるエ ストロジェン（主としてェストラジオール-17 $8: \mathrm{E}_{2}$ ) に よって促され, 雊にエストロジェンを投与すると卵管重 量が著しく増加することが古くから知られている (MunRo and Kosin, 1943)。血中 $\mathrm{E}_{2}$ 濃度は産卵期の GF ではWLとほぼ同程度であるが(小川ら，1990； Peterson and Webster, 1974 ; Shahabi et al., 1975), 成長期における濃度や卵管のエストロジェンに対する反 応性については明らかではない。そこで，本研究では， 成長初期の GF とWL について, 卵管の発育, 血中 $\mathrm{E}_{2}$ 度及びェストロジェン投与による卵管重量増加反応に差 1997 年 8 月 25 日受付 1997 年 10 月 13 日受理
違があるかどうかを明らかにしようとした。

\section{材料及び方法}

真珠斑ホロホロチョウ(GF)（Galor 社系; Jafra Trading Co., Ltd, 茨城県, より入手) と白色レグホーン 種系の卵用鶏 (WL) (H\&N 社; 松本養鵎園, 愛知県, よ り入手) のそれぞれの初生雌雊を粰化後 4 週間立体電熱 育雊器内で常時照明下で育雊した後, 群飼ケージ内（幅 $90 \mathrm{~cm}$, 奥行き $43 \mathrm{~cm}$, 高さ $35 \mathrm{~cm}$ ）に6〜9 羽ずつ収容 し, 10 週龄まで 14 時間照明 10 時間暗黒（午前 6 時点 灯）の明暗周期下で飼料と水は自由摄取として飼育し た。与えた飼料は，GF，WLのいずれに対してあ採卵鷄 の幼雊用配合飼料（平成飼料, 茨城県; CP20\% 以上, $\mathrm{ME} 2,850 \mathrm{Kcal} / \mathrm{g}$ 以上) であった。

\section{1. 体重及び卵管重量の測定}

粰化日（0 週齢）と 10 週歯までの各週齢に達した日の 一定時刻 (午後 1 時) に GF は $3 \sim 5$ 羽 (合計 44 羽), WL は 4 5 羽 (合計 54 羽) について, 各鳥の体重（g） を測定した後, 血液 $(1.5 \mathrm{ml})$ を採取した。血液採取は, 0〜2 週龄のものについては心荿から, 3 週龄以降のあの 
については翼下静脈からそれぞれへパリンで湿らせた注 射筒を使用して行った。採血後，断頭屠殺して開腹し， 卵管を摘出して重量 $(\mathrm{mg})$ を測定した。血液は, 遠心分 離 $\left(2,000 \mathrm{~g}, 10\right.$ 分間) して血漿を得, $-30^{\circ} \mathrm{C}$ 下で保存し, 採取後 8 ヶ月以内に血漿 $\mathrm{E}_{2}$ 濃度をラジオイムノアッセ イの常法（KoNo et al.,1981）に従って測定した。測定に 供した血漿の容量は $0.1 \mathrm{~m} l$, エーテル抽出は 2 回, 使用 した標識ステロイドは $[2,4,6,7-3 \mathrm{H}]$ estradiol-17 $\beta$ (比 放射能 $3.4 \mathrm{TBq} / \mathrm{mmol}$; 第一化学薬品, 東京) である。 抗血清は rabbit anti estradiol 6-CMO-BSA（帝国膤 器, 東京) を使用した。アッセイ内変動系数は $7.9 \%$ で あった。

2. エストロジェン投与による卵管重量増加反応の検 討

合成エストロジェンであるジェチルスチルベストロー ル (diethylstilbestrol : DES ; SIGMA Chemical Co, 米国)をオリーブ油（関東化学，東京）に溶解し，これ を 5 週龄 (35 日䶗) の GF (49 羽) とWL (38 羽) に 1 日 1 回連続 5 日間注射し, 最終注射の翌日 (24 時間後) に屠殺して卵管重量（mg）を測定した。DES の投与量 は 1 羽当たり $62.5,125,250,500$,及び $1,000 \mu \mathrm{g}$ とし, 注 射は毎日一定時刻（午後 1 時）に浅胸筋内に行った。注 射容量は, $0.5 \mathrm{ml}$ とし, 対照 (GF, WL 各 8 羽) はオリー ブ油 $0.5 \mathrm{ml}$ の注射を行った。また, 4 週龄の GF (54 羽) についても同様な注射を行い，卵管重量を測定した。

統計処理

2 群間の平均値間の有意差の検定には Student $の \mathrm{t}$ 検 定または, Cochran-Cox の $\mathrm{t}$ の近似法による検定を使 用した。有意差の有無は危険率 5\%で判定した。また, DES 投与による用量反応直線の検討は, 玉置（1962）が 記述した方法に従って行った。

\section{結果}

\section{0 週齡までの体重}

体重は, 図 1 に示すように, GF, WL のいずれも週齡 の進行とともに増加した。2 週龄時までは GF と WL 間 の差違は認められなかったが, 3 週齡以降の各週龄にお いては, GF の方が WLよりあ大であった。

\section{0 週齡までの卯管重量}

卵管重量は, 図 2 に示すように, GF, WL のいずれす 週龄の進行とと屯に増加した。初生時 (0 週齢)において は, GF よりあ WL の方が大であったが, $1,2,3$ 週齢で は両者間に差異は認められず，4週踚以降においては逆 に GF の方が大であった。

体重 $100 \mathrm{~g}$ 当たりの卵管重量

各週齢時に, 各個体について求めた体重 $100 \mathrm{~g}$ 当たり

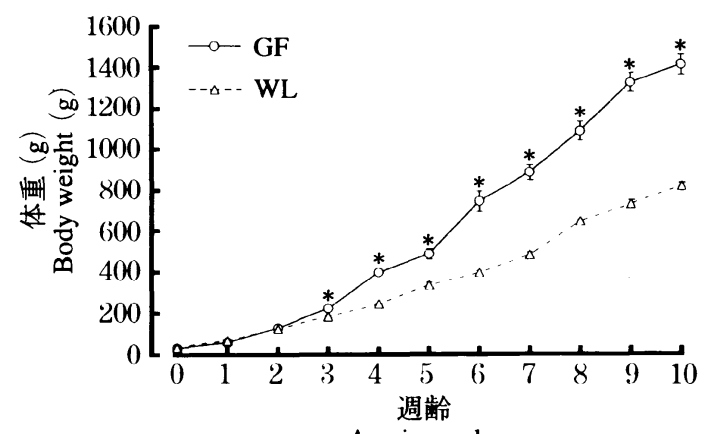

Age in weeks

困 1. ホロホロチョウ(GF) と白色レグホーン種 のニワトリ（WL）の粰化直後 (0 週龄) か ら 10 週齢までの期間における体重.

各值は, $\mathrm{GF}$ では 4 羽 (10 週齢は 3 羽), WL では 5 羽（7週龄は 4 羽）の平均値士 標準䛊差.

${ }^{*} \mathrm{GF}$ と WL の平均値間に有意差あり（ $\mathrm{P}<$ $0.05)$.

Fig. 1. Body weight of the guinea fowl (GF) and White Leghorn chickens (WL) from hatch ( 0 weeks of age) to 10 weeks of age.

Each mark with a vertical bar represents mean \pm SEM of 4 birds of GF at 10 weeks of age except for 7 weeks of age ( 3 birds) and of 5 birds of WL except for 7 weeks of age (4 birds).

* Significant difference from the value of WL $(\mathrm{P}<0.05)$.

の卵管重量は, 図 3 に示すように 2 週龄以降 10 週齡時 まで GF あWL あともに有意な変化を示さず，また， GF，WL 間の有意差も 1 週齡以降 10 週踰まで 8 週龄を 除く各週齢において認められなかった。

\section{血獎 E2 嶩度}

血漿 $\mathrm{E}_{2}$ 濃度は, $\mathrm{GF}$ においては 8 週龄時まで顥著な増 加を示さず，9週齡において増加した（図 4)。WL にお いては 4 週齢時までほとんど増加を示さず， 5 週龄以降 に増加した。 4 週龄までの濃度は GF（各週齢の値の平均 $: 18.4 \mathrm{pg} / \mathrm{ml}$ ) で WL (平均: $23.4 \mathrm{pg} / \mathrm{ml}$ ) よりあ若干低 く，6 週齡以降において GF の濃度は WL のものよりも 顕著に低かった。

\section{エストロジェン投与後の卵管重量}

GF とWLのそれぞれの 5 週龄時（35 日齢）に DES を 連続 5 日間注射し，最終注射 24 時間後における卵管重 量を表 1 に示した。GF，WLのいずれにおいても卵管重 量は DES 投与量の増加とともに増加し，投与量（対数） に対する反応（卵管重量）には直線性が成立した。回㷌 


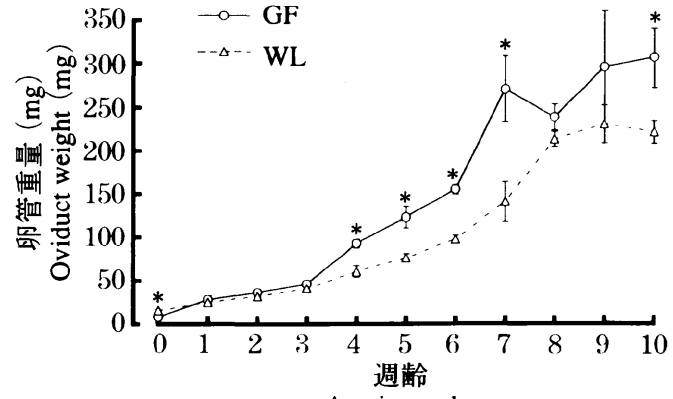

Age in weeks

図 2. ホロホロチョウ（GF）と白色レグホーン種 のニワトリ (WL) の烰化直後 (0 週齢) か ら 10 週齢までの期間におりる卵管重量. 各值は, GF では 4 羽 (10週齢は 3 羽), $\mathrm{WL}$ では 5 羽（7 週䶨は 4 羽）の平均値士 標準誤差.

${ }^{*} \mathrm{GF}$ と WL の平均值間に有意差あり（ $\mathrm{P}<$ 0.05 ).

Fig. 2. Oviduct weight of the guinea fowl (GF) and White Leghorn chickens (WL) From hatch ( 0 weeks of age) to 10 weeks of age.

Each mark with a vertical bar represents mean \pm SEM of 4 birds of GF except for 10 weeks of age ( 3 birds) and of 5 birds of WL except for 7 weeks of age (4 birds).

* Significant difference from the value of WL $(\mathrm{P}<0.05)$.

直線（用量反応直線）を計算すると, GF では卵管重量 : $\mathrm{Y}(\mathrm{mg})=1.82 \log \mathrm{X}$ (投与量 : $\mu \mathrm{g})-2.85$, WL では $\mathrm{Y}$ $=1.70 \log \mathrm{X}-2.34$ となり, 両直線の回帰係数（勾配）の 間に有意差は認められず，平行性が成立するものとみな された。卯管重量の対照に対する増加率は，GF では投 与量に応じて 4 倍から約 19 倍であったが，WLでは約 10 倍から約 37 倍であった。

同様な DES 投与を 4 週龄の GF に行った場合の結果 を表 2 に示した。投与量（対数）に対する反応には，上 記と同様に直線性が成立し，用量反応直線は $\mathrm{Y}=1.50$ $\log \mathrm{X}-2.23$ であった。また，この直線の勾配は，上記の 5 週齡時に投与した場合の GF，WL の双方の用量反応 直線の勾配との間に有意差は認められず，いずれに対し ても平行性が成立した。卵管重量の増加率は投与量に応 じて約 6 倍から約 26 倍であった。

\section{考察}

GF 及び WL の体重と卵管重量は, 週龄の増加ととも

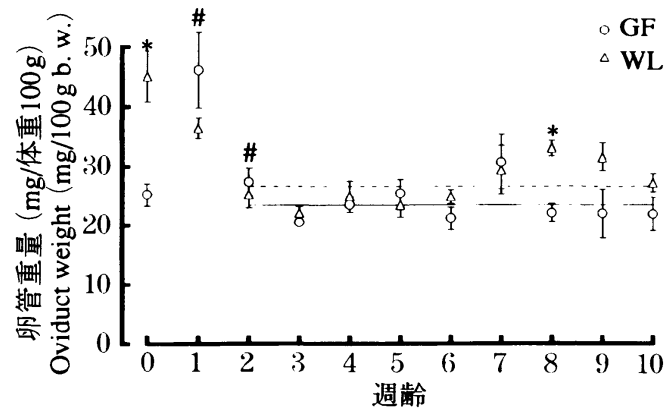

Age in weeks

図 3. ホロホロチョウ（GF）と白色レグホーン種 のニワトリ（WL）の粰化直後 (0 週齢) か ら 10 週齢までの期間における体重 $100 \mathrm{~g}$ 当 たりの卵管重量.

各值は, GF では 4 羽 (10 週齢は 3 羽), WLでは 5 羽（7週齢は 4 羽）の平均值士 標準誤差.

\# 前週の值との間に有意差あり $(\mathrm{P}<0.05)$.

* GF と WL の平均値間に有意差あり（P< 0.05).

Fig. 3. Oviduct weight per $100 \mathrm{~g}$ body weight of the guinea fowl (GF) and White Leghorn chickens (WL) from hatch (0 weeks of age) to 10 weeks of age.

Each mark with a vertical bar represents mean \pm SEM of 4 birds of GF except for 10 weeks of age ( 3 birds) and of 5 birds of WL except for 7 weeks of age (4 birds).

\# Significant difference from the value at preceding age $(\mathrm{P}<0.05)$.

* Significant difference from the value of WL $(\mathrm{P}<0.05)$.

に増加し, 体重 (図 1) は 3 週龄以降において, 卵管重量 （図 2）は 4 週龄以降において GF の方がWLよりあ大 であった。しかしながら，2 週龄以降の体重 $100 \mathrm{~g}$ 当たり の卵管重量は GFであWLでもほぼ同じであったので （図 3), 成長初期（10 週路まで）においては卵管は体の 成長ととあに発育するのであろうと考えられる。

卵管の発育は，卵巣から分泌されるエストロジェンで ある $\mathrm{E}_{2}$ によって促進されることはよく知られている (Munro and Kosin, 1943)。血中 $\mathrm{E}_{2}$ 濃度は GF において は 8 週齢までほとんど増加せずに比較的低レベル（18.4 $\mathrm{pg} / \mathrm{ml}$ ) で推移し, 8 週齡から 9 週齡にかけて増加した。 （図 4)。WL においては，血中 $\mathrm{E}_{2}$ 濃度は 4 週龄以降次第 に増加した。このような血中 $\mathrm{E}_{2}$ レベルの推移は, $\mathrm{GF}$, WL のいずれにおいても卵管重量増加の推移（図 2）と 


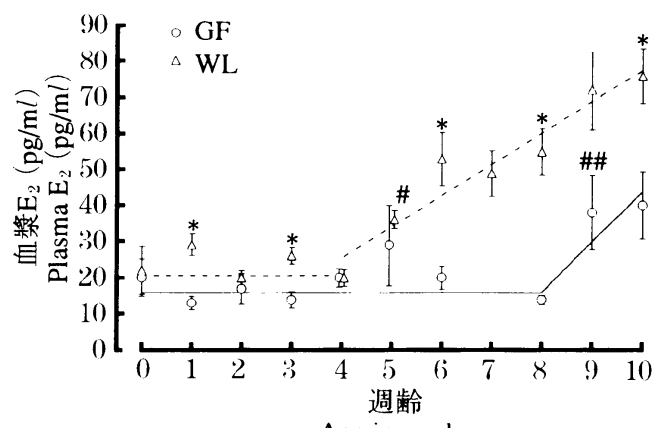

Age in weeks

闵 4. ホロホロチョウ (GF) と白色レグホーン種 のニワトリ (WL) の粰化直後 (0 週齢) か ら 10 週粭までの期間における血漿エストラ ジオール $\left(\mathrm{E}_{2}\right)$ 濃度.

各值は, GF では 4 羽 (10 週齢は 3 羽), WL では 5 羽（7週踚は 4 羽）の平均值士 標準誤差.

\#前週の值との間に有意差あり $(\mathrm{P}<0.05)$.

\#\# 0-8 週軨までの平均值との間に有意差あ り $(\mathrm{P}<0.05)$.

${ }^{*} \mathrm{GF}$ と WL の平均値間に有意差あり（ $\mathrm{P}<$ 0.05 ).

Fig. 4. Plasma estradiol-17 $\beta \quad\left(\mathrm{E}_{2}\right)$ concentration of the guinea fowl (GF) and White Leghorn chickens (WL) from hatch $(0$ weeks of age) to 10 weeks of age.

Each mark with a vertical bar represents mean \pm SEM of 4 birds of GF except for 10 weeks of age ( 3 birds) and of 5 birds of WL except for 7 weeks of age (4 birds).

\# Significant difference from preceding age $(\mathrm{P}<0.05)$.

\#\# Significant difference from the mean value between 0 and 8 weeks of age ( $P$ $<0.05)$.

* Significant difference from the value of WL $(\mathrm{P}<0.05)$.

一致しない。それ故, 成長初期においては内因性のエス トロジェンレベルは低く，卵管の発育に対する促進的作 用は発揮されていないのではないかと思われる。しかし ながら，ホルモン分泌量のレベルは必ずしもその作用の 程度を反映するものとはみなし得ないこあいわれている ので (川島, 1988), 成長初期における低いレベルの内因 性エストロジェンが卵管の発育に関与しているかどうか は更に追究する必要があろう。

I血中 $\mathrm{E}_{2}$ 濃度のレベルは $\mathrm{GF}$ の方が WLよりあ低い (図 4)。それにもかかわらず, 卵管重量は, GF の方が大
である（図 2）。もし，エストロジェンが卵管の発育に関 与するならば, GF の方が WLよりあエストロジェンに 対する反応性（重量増加）が大であってよい筈であろう。 そこで，この点を明らかにするために生体内で代謝され 難いといわれている合成エストロジェンである DES を 投与した場合の卵管重量の増加について検討した。その 結果, 5 週龄の GF と WL，4 週龄の GF のいずれにおい てあ卵管重量増加反応は $62.5 \sim 1,000 \mu \mathrm{g}$ の投与量 (対数) の範囲内で直線的に増加し，それらの回㷌直線の相互間 に平行性が認められた。従って，いずれの鳥においても DES は同じ生物学的作用機序によって卵管重量を増加 させるものであるとみなされる。

DES 投与による卵管重量の対照に対する増加率は, 同じ投与量 $(\mu \mathrm{g} /$ 羽) で比較した場合, 5 週龄の GF では 同週龄の WL よりあ劣るあのであった（表 1)。しかしな がら，GF の体重はWLよりも5 週龄において約 1.6 倍 大きいから，体重に応じて血液量も多いとすれば， 1 羽 あたりの投与量で比較するよりあ，体重当たりの投与量 で比較する方が妥当であろう。そこで，GFにおける投 与量に対する反応（卵管重量）をその $1 / 2$ の投与量にお けるWL の反応と比較してみると，そのような比較にお いても GF の方が WL よりあ劣るあのとみなされる。ま た， 5 週龄の GF の卵管重量は，同週龄の WL のものよ りあ大きい（表 1)。むし反応すべき卵管の重量の大きさ が反応に影響を及ぼすものであるならば，卵管重量が同 じであるあのに対する反応と比較すべきであろう。そこ で，4 週龄の GF は 5 週龄の WL とほぼ同じ卵管重量で あるので，4 週龄の GF に対して同様な DES 投与を行っ た。その結果（表 2）1 羽当たりの投与量で比較しても, また，体重当たりの投与量（体重は GF の方が 5 週齡の WL よりも約 1.2 倍大きい）として比較しても 4 週齡の GF の方が 5 週齡の WLよりあ反応が劣るとみなされ る。しかし，この場合の相違は週齡の相違（ $\mathrm{E}_{2}$ が少量で あっても卵管を感作するものとすれば，その感作期間の 長さの相違）に起因するものかもしれない。

以上のように，DES 投与による卵管重量増加反応は， GF ではWL よりあ劣るようであるが，断定することは 困難である。しかしながら，血中 $\mathrm{E}_{2}$ 濃度のレベルは $\mathrm{GF}$ の方が WLよりも低い（図 4）に屯かかわらず，卵管重 量は，GF の方が大である（図 2）ことから設定した仮 説，すなわちエストロジェンに対する反応性（卵管重量 増加）は GF の方が WL よりあ大であるということは亲 却できるであろう。

本実験結果は，成長初期における卵管の発育は GF で もWLでもともに体重増加と相俟って行われ, 卵管重量 増加の推移は, 血中 $\mathrm{E}_{2}$ 濃度レベルの推移と対応しない 
表 1. 5 週齢のホロホロチョウ（GF）と 5 週齢の白色レグホーン種のニワトリ（WL）に Diethylstilbestrol を連続 5 日間筋肉内に注射した後の卵管重量 ${ }^{1}$

Table 1. Weight of oviduct ${ }^{1}$ following five successive daily injections of diethylstilbestrol into 5-weekold guinea fowls (GF) and 5-week-old White Leghorn chickens (WL)

\begin{tabular}{|c|c|c|c|c|}
\hline \multirow{2}{*}{$\begin{array}{c}\text { DES 投与量 } \\
\mu \mathrm{g} / 习_{习} / \mathrm{B} \\
\mathrm{DES} \text { dose } \\
\mu \mathrm{g} / \mathrm{bird} / \mathrm{day}\end{array}$} & \multicolumn{2}{|l|}{ GF } & \multicolumn{2}{|l|}{ WL } \\
\hline & $\begin{array}{c}\text { 卵管重量 (mg) } \\
\text { Oviduct weight (mg) }\end{array}$ & $\begin{array}{c}\text { 増加率 } \\
\text { Fold increase }\end{array}$ & $\begin{array}{c}\text { 卵管重量 (mg) } \\
\text { Oviduct weight (mg) }\end{array}$ & $\begin{array}{c}\text { 増加率 } \\
\text { Fold increase }\end{array}$ \\
\hline 対照 (Vehicle 区) & $138 \pm 9^{\#}(8)^{\# \#}$ & - & $72 \pm \quad 4^{\#}(8)^{\# \#}$ & - \\
\hline 62.5 & $554 \pm 29 \quad(10)$ & 4.0 & $688 \pm 36 \quad(8)$ & 9.6 \\
\hline 125 & $867 \pm 60$ & 6.3 & $1125 \pm 68$ & 15.6 \\
\hline 250 & $1323 \pm 98 \quad(10)$ & 9.6 & $1891 \pm 148$ & 26.3 \\
\hline 500 & $2130 \pm 98$ & 15.4 & $2261 \pm 137$ & 31.4 \\
\hline 1000 & $2670 \pm 313$ & 19.3 & $2652 \pm 134 \quad(6)$ & 36.8 \\
\hline
\end{tabular}

1 最終注射の 24 時間後に摘出.

2 対照に対する倍率.

\#平均值土標準誤差.

\#\#供試羽数.

1 Removed $24 \mathrm{~h}$ after final injection.

2 Fold increase over vehicle injected control.

\# Mean \pm SEM.

\#\# No. of birds examined.

表 2. 4 週龄のホロホロチョウ (GF) にDiethylstilbestrol を連続 5 日間筋肉内に 注射した後の卵管重量 ${ }^{1}$

Table 2. Weight of oviduct ${ }^{1}$ following five successive daily injections of diethylstilbestrol into 4-week-old guinea fowls (GF)

\begin{tabular}{|c|c|c|}
\hline \multirow{2}{*}{$\begin{array}{c}\text { DES 投与量 } \\
\mu \mathrm{g} / \text { 羽/日 } \\
\text { DES dose } \\
\mu \mathrm{g} / \text { bird/day }\end{array}$} & \multicolumn{2}{|c|}{ GF } \\
\hline & $\begin{array}{c}\text { 卵管重量 (mg) } \\
\text { Oviduct weight (mg) }\end{array}$ & $\begin{array}{c}\text { 増加率 } \\
\text { Fold increase }\end{array}$ \\
\hline 対照（Vehicle 区） & $86 \pm 10^{\#} \quad(8)^{\# \#}$ & - \\
\hline 62.5 & $471 \pm 21$ & 5.5 \\
\hline 125 & $802 \pm 59$ & 9.3 \\
\hline 250 & $1554 \pm 127$ & 18.1 \\
\hline 500 & $1864 \pm 113$ & 21.7 \\
\hline 1000 & $2190 \pm 76 \quad(9)$ & 25.5 \\
\hline
\end{tabular}

1 最終注射の 24 時間後に摘出.

2 対照に対する倍率.

\#平均值土標準䛊差.

\#\#供試羽数.

1 Removed $24 \mathrm{~h}$ after final injection.

2 Fold increase over vehicle injected control.

* Mean \pm SEM.

\#\# No. of birds examined.

ことを示すあのであり，また，成長初期における卵管重 量は GF の方が WLよりも大きいが, その理由として, 血中 $\mathrm{E}_{2}$ 濃度レベルの相違やエストロジェンに対する反 応性の相違は考え難く, 体成長の程度の差異の影響が大
きいことを示唆するものといえよう。

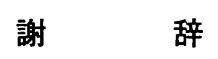

本研究を実施するにあたり, 終始実験に協力された那 
須井雄君ならびに栢野千穂嬢に感謝いたします。本研究 は, 平成 9 年度文部省科学研究費補助金 (基盤研究 (C), 課題番号 : 09660294）による助成を受けた。

\section{文献}

川島光夫 (1988) 家禽における性ステロイドホルモンの 生理作用一レセプターを中心として一。日本畜産学会 報, $59: 225-234$.

Kono, T., ITOH, H. and ICHINOE, K. (1981)Measurement of sex steroid hormones in blood plasma and follicle of chickens by radioimmunoassay. Journal of Agricultural Science, Tokyo Nogyo Daigaku, Commemoration Number of the $90^{\text {th }}$ Anniversary of Foundation : 257-265.

MunRo, S.S. and Kosin, I.L. (1943)Dramatic response of the chick oviduct to estrogen. Poultry Science, 22 : 330-331.
小川 博・桑山岳人・一戸健司 (1990) 䊒ホロホロ鳥に おりる産卵率, 血中プロジェステロン, テストステロ ンおよびェストラジオール濃度の年内変動. 日本家昺 学会誌, $27: 373-378$.

Ogawa, H., Kuwayama, T. and TanaKa, K. (1996)The timing of ovulation after oviposition and the time spent by the ovum in each portion of oviduct in the guinea fowl. Japanese Poultry Science, 33 : 118-122.

Peterson, A.J. and Webster, M. (1974)Oestrogen concentration in the peripheral plasma of maturing pullets. British Poultry Science, 15 : 569-572.

Shahabi, N.A., Norton, H.W. and Nalbandov, A.V. (1975)Steroid levels in follicles and plasma of hens during the ovulatory cycle. Endocrinology, 96 : 962 -968 .

玉置文一 (1962) 生物学的試験法における統計的方法, 推 計学の化学及び生物学への応用 第 2 集 Bioassay 推計学 (化学の領域増刊 II ).9-13 頁, 南江堂, 東京. 


\title{
Early Growth of Oviduct, Changes in Plasma Estradiol-17 $\beta$ Concentration and Response to Estrogen for Weight Increase of Oviduct in the Guinea Fowl and White Leghorn Chickens
}

\author{
Hiroshi Ogawa ${ }^{1}$, Takehito Kuwayama ${ }^{2}$ and Katuhide Tanaka ${ }^{2}$ \\ ${ }^{1}$ Fuji Zootechnical Station, Tokyo University of Agriculture, Fujinomiya-shi 418-0109 \\ ${ }^{2}$ Department of Zootechnical Science, Tokyo University of Agriculture, Tokyo 156-0054
}

Body weight, oviduct weight and plasma estradiol-17 $\beta\left(\mathrm{E}_{2}\right)$ concentration were measured at every week from hatch to 10 weeks of age in guinea fowl (GF) and White Leghorn chickens (WL). The body weight was greater in GF than in WL from 3 weeks of age, and the oviduct weight was also greater in GF from 4 weeks of age. The oviduct weight per $100 \mathrm{~g}$ body weight did not show any appreciable change from 2 weeks of age in both GF and WL, and no difference was observed between them. Plasma $\mathrm{E}_{2}$ concentration did not change up to 8 weeks of age in GF, but increased after 4 weeks of age in WL. When diethylstilbestrol was injected once daily for 5 consecutive days into GF and WL at 5 weeks of age, the oviduct weight on 6 th day was found to be increased linearly with the increase in the daily dose injected $(62.5-1,000 \mu \mathrm{g} / \mathrm{bird})$. The response (fold-increase over the control) of GF was less than that of WL. Similar injections were also made into GF at 4 weeks of age, and the response was also less than that of WL at 5 weeks of age. The results suggest that the greater oviduct weight in GF than in WL during an early growth period may be due neither to the estrogen secretion nor to the responsiveness to estrogen.

(Jpn. Poult. Sci, $35: 125-131,1998)$

Key words : oviduct growth, guinea fowl, plasma estradiol, diethylstilbestrol 